\title{
Two Coptic Prayers on Ostracon (P.Berol. 709 and 9444+4790)
}

\author{
Ágnes T. Mihálykó*
}

\begin{abstract}
Edition, with philological and liturgical commentary, of two Theban 7th/8th century liturgical prayers in Sahidic Coptic from the Berlin Papyrus Collection. The first prayer is an unattested redaction of the intercession for peace, related to the wording of the anaphora of St. Mark. The second is a long and elaborate prayer of thanksgiving, asking for protection. It parallels the first prayer of the morning of the present-day Coptic rite.
\end{abstract}

Keywords: prayer, intercession, anaphora of St. Mark, liturgy of the hours, Thebes

https://doi.org/10.1515/apf-2019-0008

In his still fundamental summary of the literature in Western Thebes Walter E. Crum compiled a list of prayers written on ostraca of pottery and limestone, which witness the liturgy of the monasteries in the area. ${ }^{1}$ The two ostraca to be edited here for the first time were already included in this list, ${ }^{2}$ identified as a prayer "for Peace" and a prayer "at Morning Incense", but they have not been paid further attention until now in spite of their interest for the history of the liturgy in Egypt. P.Berol. 709 contains an idiosyncratic variant of the intercession for the peace, different from the ones previously known from the area (P.Moscow Copt. 95 and

Vorbemerkung: I owe the permission to publish these ostraca to Prof. Verena Lepper, to whom I express my gratitude for providing the images as well. I also thank Anne Boud'hors for her comments on the editions.

*Kontakt: Ágnes T. Mihálykó, Dept. of Philosophy, Classics, History of Art and Ideas, Faculty of Humanities, University of Oslo, 0313 Oslo, Norway <a.m.tothne@ifikk.uio.no>

${ }^{1}$ Herbert E. Winlock and Walter E. Crum, The Monastery of Epiphanius at Thebes. Vol. I (New York, 1926), 198-199.

${ }^{2}$ The third Berlin ostracon included in his list, P.Berol. 1086, has been recognized by the author as the bottom of BM EA 14180 (O.Brit. Mus. Copt. I p. 24. pl. 18.3) containing the same prayer in a different redaction as O.Frangé 730 and has been edited in the Journal of Coptic Studies 21 (2019), 161-173. 
perhaps O.Petr. Mus. 19) with an unusual focus on the external enemies. P.Berol. $9444+4790$ is a long and sophisticated prayer with unexpected

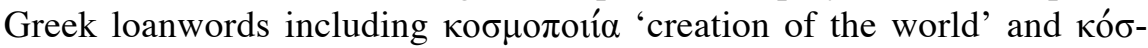
$\mu \circ \varsigma$ in the meaning 'beauty', which can possibly be recognized as the prayer for the morning service. This article, besides editing the texts based on autopsy of the objects, also attempts to situate them in the context of the late antique liturgy in Egypt and in particular in Western Thebes.

\section{P.Berol. 709: intercession for peace}

Western Thebes?

$\mathrm{h} 10.2 \times \mathrm{w} 7.1 \mathrm{~cm}$

Seventh or early eighth century

The irregular piece of reddish pottery preserves on both sides a Sahidic version of the intercessions for peace. ${ }^{3}$ The ostracon is complete except for the bottom. The text is penned with black ink in sloping majuscules. The scribe began the prayer on the inner, convex side. He wrote the first six lines of the prayer in larger and thicker letters but continued in smaller letters from 1. 7. The writing on the outer, concave side is also larger and thicker. Despite the uneven writing, the similarity of the letter forms suggests that the scribe was the same on the whole ostracon. The text is faded in some places and the outer side was left blank after the end of the prayer.

The writing style is sloping majuscule with a not very marked angle. The letter forms are simple, without decorative hooks, and the line distance is minimal. $\boldsymbol{\alpha}$ has a round belly and a straight back, the crossbar of $\mathbf{H}$ is ascending towards the right, $\mathrm{K}$ is straight and not split, $\mathrm{M}$ is done in three strokes, $\mathbf{O}$ is small but not reduced to a dot. The hand resembles that of Mark the priest of the topos of St. Mark, especially his less formal writing as on O.Saint-Marc 130, although our scribe does not have the level of sophistication Mark's style reaches. Another good parallel is P.Mon. Epiph. 597. On the basis of these parallels the hand might be dated to the early seventh century, but due to conservative tendencies in the region the rest of the seventh century and the early eighth cannot be excluded either. Although the piece was acquired in Cairo through the antiquities market, the style of the hand, reinforced by the close parallels from

\footnotetext{
${ }^{3}$ The contents were first identified by Walter E. Crum in Winlock and Crum, The Monastery of Epiphanius Vol.I, 199. Walter Beltz, "Katalog der koptischen Handschriften der Papyrus-Sammlung der Staatlichen Museen zu Berlin. Teil II," Archiv für Papyrusforschung 27 (1980), 128, IV 129 suggested, mistakenly, that it was a letter.
} 
Western Thebes, supports the suggestion by Crum that the ostracon comes from this area, where the absolute majority of liturgical ostraca were written. ${ }^{4}$

The language of the prayer is regular Sahidic, but the scribe writes NEMEN for NMM $\bar{M}$ N (1. 12), drops a $N$ from C)גN2TH4, and spells 6 consistently with a K (TENKENBWK for TENGINBWK in 11.16 and 17, Кепн for бєпн in 1. 22, єчскд22T for єчсбрдарт in 1. 24). This latter is a feature typical of the Theban area, ${ }^{5}$ which again supports the provenance. The scribe was copying from an exemplar, as evidenced by his mistake in 1.9, where he, lead visually by the two $\omega$-s in $x \omega \omega$ pe in the line below, started writing two $\omega$-s also after ekeTd () , the first of which he corrected into q, while he left the other one in place. This confusion induced him to exchange in Tג(G) 4 the feminine personal pronoun referring to EIPHNH into a masculine one. He moreover mixed up 1. 23, where he reduplicated $2 €$, then started copying €q2ג, probably for €q2גpK, which he abandoned, and continued with the other verb. He also dropped $\mathbf{\epsilon}$ from €тоүадв in 1. 7.

The text is an intercession for peace. Such intercessions, for peace and other topics (such as the patriarch, the fruits of earth, or the deceased members of the community), can be found both as alone-standing prayers with an invocation of God and a final doxology, and as part of a sequence of intercessions in the anaphoras. The independent intercessions and the intercessions inside the anaphora concerning the same topic often share phrases or entire sequences. The independent intercession for the peace was already part of the Eucharistic service in the fifth century Alexandria and was recited together with a request for the patriarch and for the congregation after the departure of the catechumens and before the anaphora. ${ }^{6}$ In the present-day Coptic service it stands at the very beginning of the liturgy of the faithful after the prayer of the veil, as the first of the Three Great Prayers, recited for the peace, the patriarch, and the con-

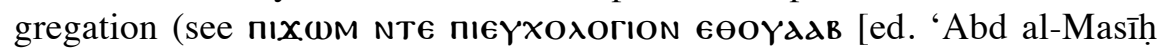
Salīb; Cairo, 1902], 276-279). The intercession for the peace within the anaphora of St. Mark (also called of St. Cyril), where it begins the chain

\footnotetext{
${ }^{4}$ On liturgical ostraca see Ágnes T. Mihálykó, The Christian Liturgical Papyri: An Introduction (Tübingen: Mohr Siebeck, 2019), 166-167.

${ }^{5}$ Paul E. Kahle, Bala'izah: Coptic Texts from Deir el-Bala'izah in Upper Egypt (London: Oxford University Press, 1954), 147.

${ }^{6}$ Heinzgerd Brakmann, "Le déroulement de la Messe copte. Structure et histoire," in L'eucharistie: célébrations, rites, piétés (ed. A.M. Triacca and A. Pistoia; Roma: C.L.V. Edizioni liturgiche, 1995), 120.
} 
of intercessions, coincides with this text to a large degree. The first attestation of the intercession within the anaphora is in P.Strasb. inv. 254 (fourth-fifth century, ed. Jürgen Hammerstaedt, Griechische Anaphorenfragmente aus Ägypten und Nubien [Pap.Colon. XXVIII, Opladen: Springer Fachmedien Wiesbaden, 1999], 21-41). This short version of the intercession in P.Strasb. inv. 254 was expanded with additional phrases in the various redactions. The stock expressions and sequences of cola that accumulate in these redactions, both in the anaphora and in independent intercessions, add up to what might be called the 'Markan tradition' of this intercession (and of all other intercessions). ${ }^{7}$

P.Berol.709, as it begins straight with an invocation of God and is not continued on the verso with other requests, seems to be an independent intercession. It may belong to the preanaphoral part of the Eucharist, but this is not the only possibility, as independent intercessions appear also in other rites and not only in the Eucharist, e.g. the morning and evening offering of incense. Against this hypothesis speaks the lack of doxology and title, which is typical for copies of independent intercessions (e.g. O.Petr. Mus. 19, P.Moscow Copt. 95, P.Bal. I 30 fol. 9). Thus it cannot be excluded completely that the text was rather an extract from an anaphora, perhaps an alternative for the intercession for the peace, to be inserted in a complete anaphora. However, as the doxology could have been dropped due to its familiarity and titles can also be lacking in an informal copy (it is not added before the intercession for the dead in P.Ryl. III 465v either), it is more probable that the text was an independent intercession rather than an extract from an anaphora.

The exact wording of the intercession for the peace recorded on P.Berol. 709 or a version in another language is not attested in any other copies to my knowledge. It differs also from two other redactions of the same prayer from the region, P.Moscow Copt. 95 in Sahidic and O.Petr. Mus. 19 in Greek. ${ }^{8}$ Its text is nonetheless not completely unknown, as it is to a large extent a patchwork of phraseology attested also in other intercessions from the Egyptian liturgy, a typical feature of intercessions preserved on papyrus. Thus the citation from Ps. 120:8 in 11. 16-18 appears in

\footnotetext{
${ }^{7}$ On the intercessions of the anaphora of St. Mark and the preanaphoral intercessions, see Hieronymus Engberding, "Das anaphorische Fürbittegebet der griechischen Markusliturgie," Orientalia Christiana Periodica 30 (1964) 398-446, although many of his conclusions are outdated.

${ }^{8}$ The provenance of this ostracon from the Theban region is uncertain, another, though less likely possibility is Dendera, see O.Petr. Mus. 19 p. 5.
} 
the 'Markan tradition' for the intercession for peace and for the patriarch. The introduction (11. 4-7) is shared with the intercession for the peace on P.Moscow Copt. 95, r.14-15, and the same prayer has a variant of 11. 2024 as well, which is furthermore shared with the intercession for the emperor in the anaphora of St. Mark/Cyril in certain redactions (e.g. that in the Great Euchologium, p. 39.4-5 (Emmanuel Lanne, Le Grand Euchologe du Monastère Blanc [Turnhout: Brepols, 1958], 292). The opening request in 11. 8-10 also draws on the formulation of the anaphora of St. Mark/Cyril, but it incorporates a phrase from Phil. 4:7. The section in 11. 10-15 has on the other hand no direct parallels and exhibits a unique emphasis on war and physical enemies otherwise absent from intercessions for peace. It is connected to a section of the intercession for peace in the 'Markan tradition', but that text prays for the safety of the own soldiers and rulers instead of the defeat of the enemy. The idiosyncratic character of the section might indicate that it was a local feature, or perhaps even a temporally restricted variation, inspired by the turbulences of the seventh century, the Persian and the Arab invasions (for this, see commentary to 11. 10-16). However, as we have this single, somewhat muddled copy of the prayer and thus no clues for the extent of its circulation, such a suggestion must remain a speculation.

\section{inner side}

$1 \quad[\mathrm{~T}] \mathrm{N} \operatorname{con} \mathrm{AY} \cdot[\omega] \mathrm{T} \overline{\mathrm{N}}-$

паPגKaגeI MM $[\mathrm{OK}]$

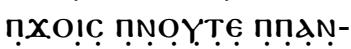

TOKРАTWP ETBE

5 TEIPHNH N

$\lambda[1] K H$ EKK入HCIA

$<\in T>O Y A d B$ MaYAdC $X \in K A C$

TEKEPHNH ETXOCE EMEEYE

NIM EKETd()ч $\{\omega\}$ E2PAï

$102 \mathrm{~N} N \bar{N} 2 \mathrm{HT}$ NГ $X \omega \omega \mathrm{X} \in \mathrm{EBO \lambda}$

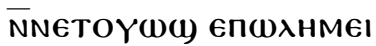

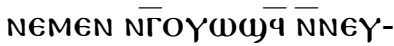

MEEYE N2HT MMATOI

MN NTHMOC ETEXEKE 2H-

$15[r] € M M N$ MN NEחגPXOC

[NTKOCM] $]$ ! NTENKENBWK 

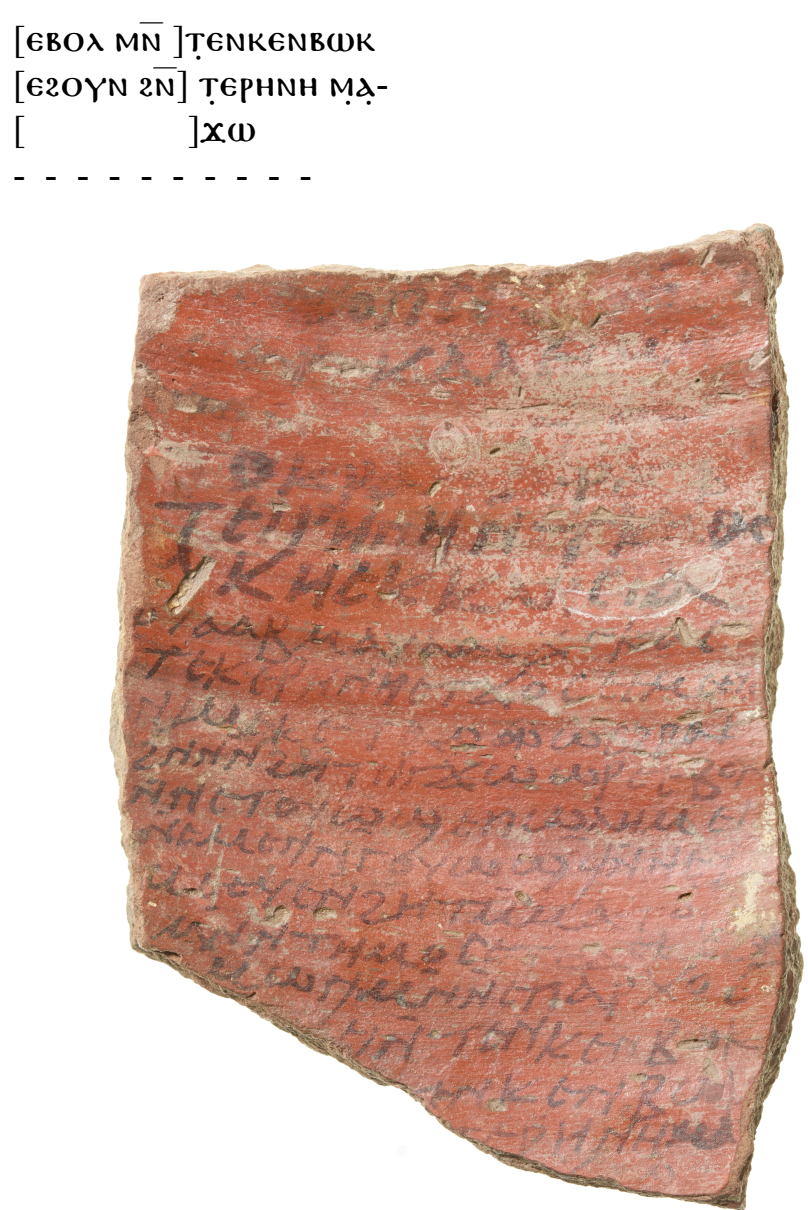

P.Berol. 709, S. 1

(C) Staatliche Museen zu Berlin, Ägyptisches Museum und Papyrussammlung 


\section{outer side}

20 MAPENEKMNT-

()ג2THY TA2ON 2NOYKEחH ETPENEIPE $\bar{N}$ OYd2€ $\{2 \epsilon \in 42 d\}$ G4CKA22T NAN $\%$

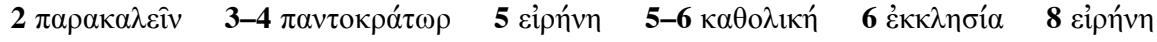

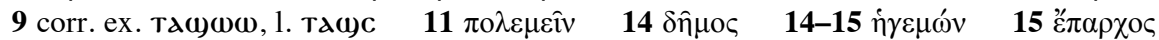

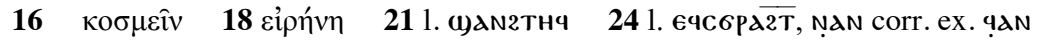

\section{8-9 Phil. 4:7 16-18 Ps. 120:8}

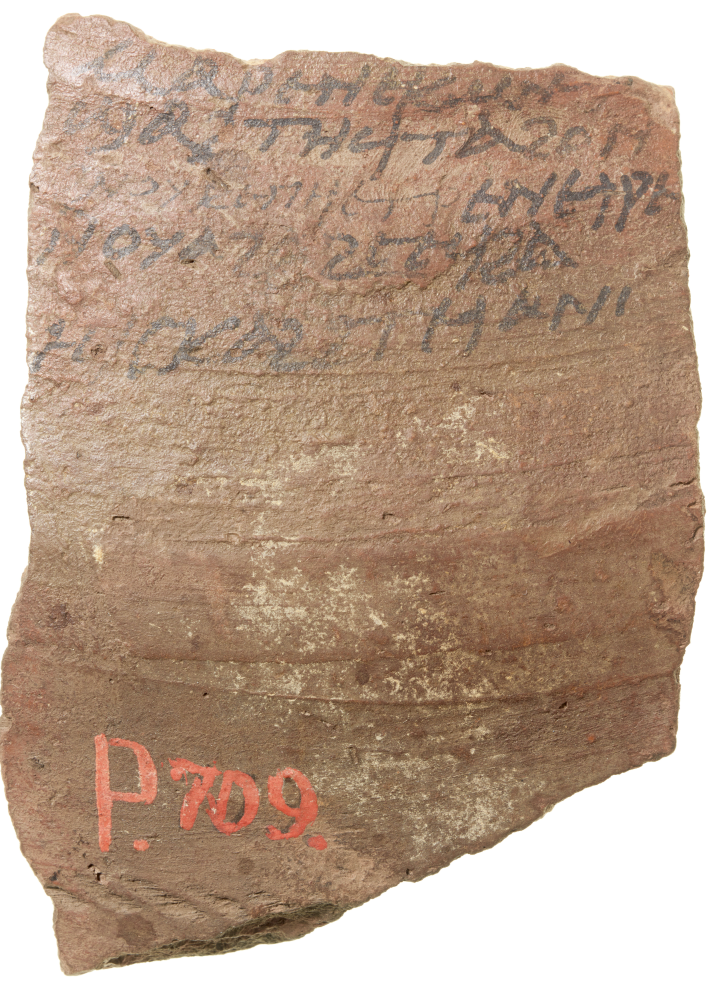

P.Berol. 709, S. 2

(C) Staatliche Museen zu Berlin, Ägyptisches Museum und Papyrussammlung 


\section{Translation}

We beg and we beseech you Lord, God Almighty for $I^{5}$ the peace of the I one holy I catholic Church, I establish your peace that surpasses all thought $I^{10}$ into our hearts, destroy those who want to wage war with us, crush their thoughts (of?) the soldiers and the people that $\ldots 1^{15}$ hegemon and the eparchs, and adorn our going in and our going out in peace... ${ }^{20}$ may your mercies come upon us quickly so that we live a life that is quiet to us.

\section{Commentary}

1-7 The intercession begins with a stereotyped request to God, similarly to the intercessions of the anaphora of St. Mark/Cyril in Prague, Or. Inst. MS II p. 4.4-5 (Valerie Hažmuková, "Miscellaneous Coptic Prayers II," Archiv Orientální 9 [1937] 122). The peace of the church is expressed probably with the same expression in P.Moscow Copt. 95, where however only етве TрнNн at the end of r.14 and maydac at the beginning of the next line is preserved. The Church attracts various attributes in liturgical language. The standard four of the Alexandrian liturgy is ó $\gamma^{\prime} \alpha, \mu o ́ v \eta$,

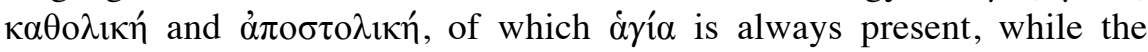
others are variable (Achim Budde, Die ägyptische Basilios-Anaphora. Text-Kommentar-Geschichte. [Münster: Aschendorff, 2004], 435). The presence of the adjective $\mu$ óvn is an Egyptian characteristic visible already in the fourth-fifth century in P.Strasb. inv. 254 r.20 (Hammerstaedt, Griechische Anaphorenfragmente, 24). In Sahidic it is translated as reloyel MaYdac in the Great Euchologium, p. 101.24 (Lanne, Le Grand Euchologe, 312), while Louvain, Ms Lefort copt. 28A fol. IV r.16-17 (ed. Jean Doresse and Emmanuel Lanne, Un témoin archaïque de la liturgie copte de S. Basile. [Louvain, Institut Orientaliste-Publications Universitaires, 1960], 22) offers the translation [6]Toyalac. Here the simple solution maYdac is chosen.

7-10 The formulation of the request for the intercession is close to that of the anaphora of St. Mark/Cyril, as evidenced already in the first

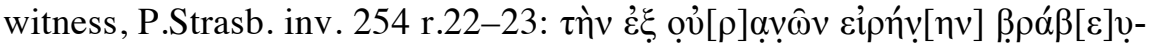

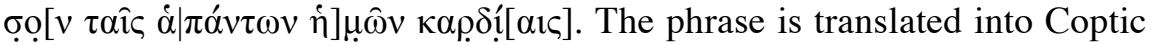

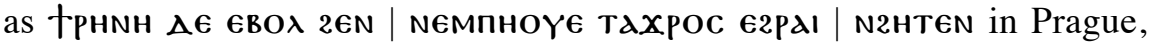
Or. Inst. MS II p. 4.10-12 (Hažmuková, "Miscellaneous Coptic Prayers

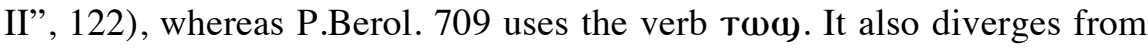
the 'Markan' wording in introducing текернNн етхосе емєеүє NIM 
from Phil. 4:7 instead of the 'peace from heaven'. The wording of the Pauline citation corresponds to the text of the Sahidic Bible (G.W. Horner, The Coptic Version of the New Testament in the Southern Dialect. Vol. V. The Epistles of Saint Paul (continued). [Oxford: Clarendon Press, 1920], 308).

10-16 This section of the intercession, placed after the initial request for peace and before the citation of Ps. 120:8, which asks for the destruction of the enemies, diverges from all other known wordings of the intercession for peace. The lack of parallels, together with some likely irregu-

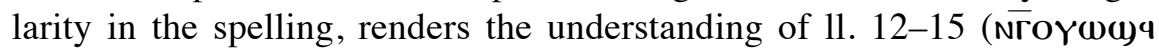

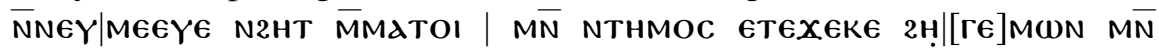
Nenapxoc) difficult. The letters are clear with the exception of the $\mathbf{H}$ at the end of 1. 14, but as they stand, they do not make sense. Two unclear points obscure the meaning: the syntactical role of MMATOI I M $\bar{N}$ NTHMOC and the meaning of eтєxєкє. For the first we may either suppose that they develop the third person plural of the possessive article of $\bar{N} N \in Y-$ ME€Y€, in which case an extra possessive $\bar{N}$ should be restored before MMATOI and the phrase should be translated as "destroy their thoughts, of the soldiers and the people". However, we might also assume that these words are objects of a verb which has disappeared, the meaning of which could have been something like "destroy". As for eтexeke, we may

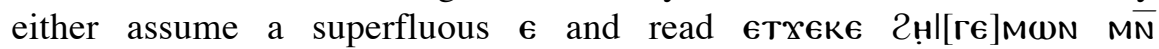
NGnapxoc "that sting the hegemon and the eparchs", which might develop "the soldiers and the people", or "their thoughts". What precisely that would mean remains unclear; it might refer to disobedient people and armies, which annoy the rulers with rebellious thoughts. Another option is to suppose the loss of two Ns and restore ETEXNE NKE2HгEMWN "that destroy also the hegemons and the eparchs", which is best taken to "the soldiers and the people". If this is accepted, does the text speak of foreign armies that defeat the local officers? Due to the distortions in the text, these suggestions remain uncertain.

The corresponding intercession from the 'Markan tradition' has a similar section in this position, already present in the earliest extant redaction,

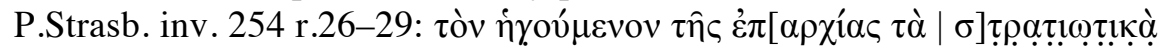

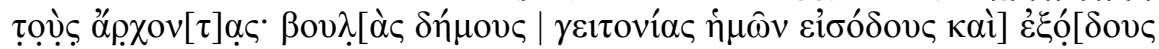

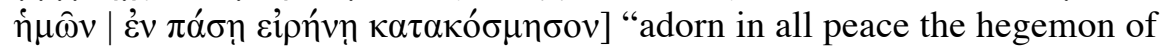
the eparchy, the military, the leaders, the councils, the people, our neighbourhoods, our going in and our going out". P.Berol. 709.10-16 
seems to be a variation of this phrase or a phrase similar to it, even using some of the vocabulary, as mMdTO (which translates $\tau \grave{\alpha} \sigma \tau \rho \alpha \tau 1 \omega \tau \iota \kappa \alpha ́$ also in the corresponding section of Prague, Or. Inst. MS II p. 4.15 [Hažmuková, "Miscellaneous Coptic Prayers II", 122], тнм0с, which also appears in the list of O.Petr. Mus. 19 r.4 (and perhaps also in P.Strasb. inv. 254 r.27, now in the lacuna). Moreover, the words 2нгеMWN MN NendP-

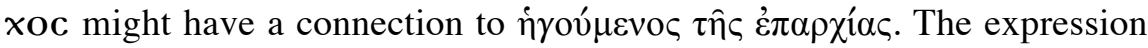
appears only in P.Strasb. inv. 254, it is already absent from the next witness of the prayer in time, the anaphora of St. Mark and the independent intercession for peace included in the Aksumite canonicoliturgical collection, the text of which dates from the end of the fifth or beginning of the sixth century. ${ }^{9}$ The uniqueness of the mention of this office in P.Strasb. inv. 254 and its subsequent disappearance underscores the observation of Hammerstaedt (Griechische Anaphorenfragmente, 34),

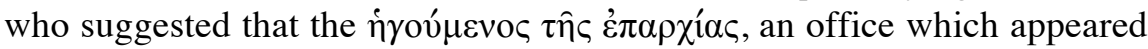
with the reforms of Diocletian at the end of the third century, would probably only be mentioned second after the emperor as long as the prefects of the Egyptian provinces communicated directly with the emperor, but not after 380/382, when the prefectus augustalis of the diocese Aegyptus became their direct boss. Moreover, from the fifth century on the word ir $\gamma$ ov́ $\mu \varepsilon v o \varsigma$ is increasingly reserved for the leaders of monasteries. In such a situation it can be imagined that with time the

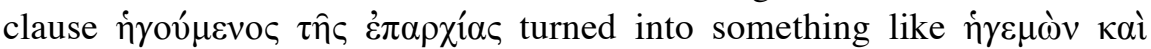
$\varepsilon \pi \alpha \rho \chi 0 \varsigma$ in a local variant instead of dropping out, and this modified clause was picked up by the author of the prayer on P.Berol. 709 .

In spite of the parallels of vocabulary, the list of officers and soldiers plays an opposite role in P.Berol. 709 to what it usually does in the intercessions for peace. Whereas in the wording of the anaphora of St. Mark

\footnotetext{
${ }^{9}$ I owe this information to Reinhard Messner. The Aksumite canonico-liturgical collection is preserved in a medieval Ethiopic manuscript, but goes back to a late antique translation of an Alexandrian canonical collection, made directly from the Greek. On the manuscript, see Alessandro Bausi, "La Collezione aksumita canonico-liturgica," Adamantius 12 (2006) 43-70, especially 45 and 60-61. The liturgical texts of the Aksumite collection are not yet edited, but an English translation of the independent intercession for the king, the anaphora of St. Mark, the anaphora of the Apostles, and the prayers following the anaphoras are available in Emmanuel Fritsch, "New Reflections on the Late Antique and Medieval Ethiopian Liturgy," in Liturgy's Imagined Past/s: Methodologies and Materials in the Writing of Liturgical History Today (ed. Teresa Berger and Bryan D. Spinks; Collegeville, Minn.: Liturgical Press, 2016), 44 and 47-54.
} 
the request is made for the own kings, officers, armies, and people to live in peace, here the request is made for crushing the enemies and their evil intentions. Such requests with explicit reference to war are not to be found in other requests for peace. Indeed, the only intercessions where physical war is referred to are the independent intercession for the emperor in the Aksumite collection and the intercession for the emperor in the anaphora of St. Mark/Cyril. In the intercession of the Aksumite collection God is asked to "submit the enemy, the nations" (Fritsch, "New Reflections", 44). The same phrase reads as "submit all the barbaric people who want war" in the redaction of the anaphora of St. Mark/Cyril of the Kacmarcik codex, whereas in the same text the deacon's call asks to "subdue to them all

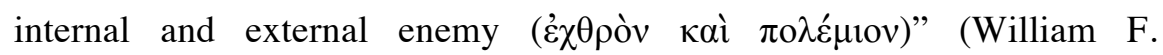
Macomber, "The Anaphora of Saint Mark According to the Kacmarcik Codex," Orientalia Christiana Periodica 45 [1979] 83-84). Intercessions for the patriarch and for the congregation also speak of enemies and their dispersal. The intercession for the congregation on BKT VI $72 \mathrm{v} 11.21-25$

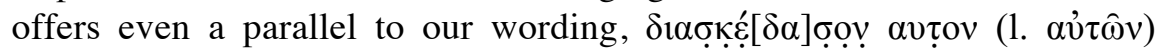

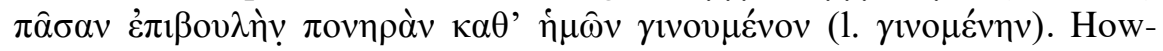
ever, these latter intercessions speak of spiritual war with demons or conflict with internal enemies rather than actual war. Thus the long, elaborate request for the defeat of enemies is without good parallels. This uniqueness of the expression as well as its connection to the list of secular authorities in the intercession for peace in the 'Markan tradition' raises the possibility that this might be a secondary development, a variation bound to the historical situation in which the ostracon was copied. The first half of the seventh century was marked by the invasion of the Persians and the Arabs, which events might have prompted a temporary shift of focus from the peace of the own troops to the defeat of the enemy. However, this interpretation is rather uncertain, especially in view of the textual problems of the copy and the lack of information on the circulation of this redaction. Thus the text might not be anything else than a local variant of the intercession for peace without any particular connection to the turbulent events of the seventh century.

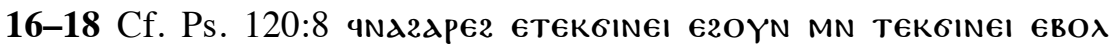
(E.A. Wallis Budge, The Earliest Known Coptic Psalter. [London: Kegan $\mathrm{Paul} /$ Trench/Trübner, 1898], 135). This expression is included in the intercession for peace in the 'Markan tradition', it is present already in P.Strasb. inv. 254 r.27. The Sahidic translation of Prague, Or.Inst. MS II 


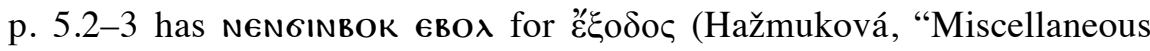
Coptic Prayers II", 122).

18-19 The text cannot be reconstructed, as the ostracon breaks off. It is unclear how much was lost.

20-24 The same expressions can be restored on P.Moscow Copt.

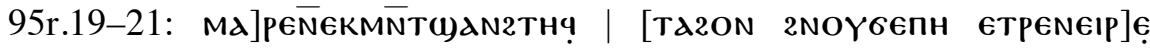

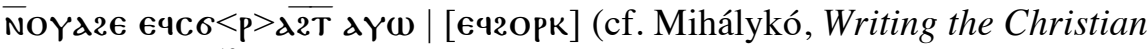
Liturgy, 284). ${ }^{10}$ The supplement of the second verb is based on a parallel in the intercession for the emperor of the anaphora of St. Mark/Cyril in the

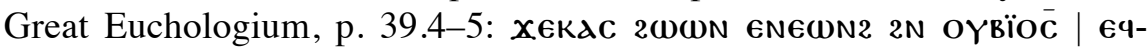
сорд2т дүш єчгорк (Lanne, Le Grand Euchologe, 292). The verb єчгорк might have been intended as well in $\mathbf{6 4 2 d}$, but the second half of the verb together with the conjunction might have been dropped. This would mean an inverted order of the clauses compared to the order in P.Moscow Copt. 95 and in the wording of the anaphora. Whatever his exemplar might have been, the scribe apparently got confused, reduplicated $2 \epsilon$, started copying Eч2дрк, which he did not finish, and passed on to the other verb, €qCKд22T, where he inserted a superfluous 2 (the $P$ is also missing in P.Moscow Copt. 95.20 and might have been the orthography of the place and period). P.Berol. 709 finishes with a redundant NaN, but P.Moscow Copt. 95 and the intercessions for the king from the anaphora continue with a phrase NCE2E EPON $2 \mathrm{~N}$ | MNTEYCEBHC NÏM MN MNTCEMNOC NïM (Lanne, Le Grand Euchologe, 292), which leads to the doxology. This phrase and the doxology are missing here, although there was ample space. The scribe might not have considered the doxology necessary, as it was standard.

\footnotetext{
${ }^{10}$ The end of this phrase is also found at the end of the independent intercession for peace in the Aksumite collection, as I have been informed by Reinhard Messner.
} 


\section{P.Berol. 9444+4970: morning prayer}

Western Thebes $^{11}$ h27 $\times$ w $23.7 \mathrm{~cm} \quad$ Seventh or early eighth century

The three pieces of limestone, which join and belong to the same ostracon of considerable size, contain a prayer with thanksgiving and request for protection, probably a prayer for the morning. ${ }^{12}$ The two pieces of inv. 4970 join along a long edge. They were bought together, have been recognized as belonging together, and were catalogued together. Inv. 9444, which was bought separately, also joins along the lower edge with inv. 4970 on the front, and on the back a short part of the lower right edge of inv. 9444 connects to the upper left edge of inv. 4970A (11. 32-33, in 1. 32 $\mathrm{N}$ and in $1.33 \mathrm{c}$ is on both ostraca). Close to all margins of inv. 9444 have been preserved almost completely, with only the lower right and left edges being incomplete. However, much is chipped away from the surface on both sides. The two pieces of inv. 4970 also have almost complete edges, except for fragment $\mathrm{A}$, where the upper right edge (front) is broken. The surface is damaged also here, especially on the verso. Even where the surface is intact, some letters are faded. Due to the damaged surface some line ends and beginnings, sometimes up to half of the line, as well as the entire 1. 10, are lost (11. 6-13 of the front and several lines of the back). The damage prevents the reconstruction of some of the text.

The text starts with a staurogram. Cola are divided irregularly with short curving strokes placed in the upper index. In 1.15 and 23 a double dot is used to divide two larger sections, and in 1.27 a high dot is used for the same purpose. The scribe corrected himself in 1.2 by rubbing out a word.

The writing is a large and informal upright majuscule. It resembles the writing of Psate and Sousanna, who wrote to the monk Frange in the early eighth century (e.g. O.Frangé 353-356). This would suggest a date into the early eighth century. However, similar informal majuscules can be recovered from the early seventh century as well, e.g. O.Saint-Marc 73

\footnotetext{
${ }^{11}$ Both items were bought in Thebes, 4970 in 1889 , and 9444 in 1890 . The material, limestone, which was used for writing texts especially in the monasteries of Western Thebes, also suggests one of these monasteries or hermitages as the origin.

${ }^{12}$ They were first recognized as prayers and as belonging together by Walter E. Crum in Winlock and Crum, The Monastery of Epiphanius, Vol.I, 199. Subsequently Walter Beltz ("Katalog Teil II", 172, IV 1045 and 1050) catalogued them separately, inv. 4970 as a prayer and 9444 as a hymn.
} 
and 74, written to Mark of the topos of Saint Mark. Thus both the seventh and the early eighth centuries, the entire period of activity of the monasteries of Western Thebes, remain possible.

The language of the prayers is a relatively pure Sahidic. The original Greek is transparent in several loanwords, some of which show a degree of sophistication, especially кó $\mu$ os in the classical meaning of 'beauty,

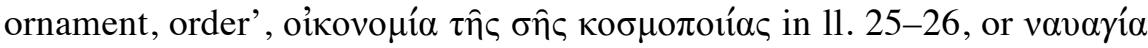
in 11. 34-35. The parallel constructions of 11. 11-15 also suggest a rhetorically elaborate original (cf. commentary to lines).

The three fragments preserve one or less probably two prayers. The number of the prayers depends on the interpretation of 11. 20-21 on the back. L. 21 preserves rests of a doxology, which might close the first prayer; thus 1.22 would open a new prayer. However, in this case the first prayer would be virtually without a request. Also, what remains of 1.22 does not suggest an opening with an invocation of God. Therefore it is more likely that we are faced with only one long prayer. In this case, the doxology of 1.21 can be understood as the end of the doxology begun but not finished in 11. 42-43. The scribe, forced by the lack of space, copied the end of the doxology on the top margin in slightly smaller letters. While it is curious that the scribe considered it necessary to copy the end of a simple doxology, the most conventional part of a prayer, in extenso, this is exactly what the scribe of O.Frangé 730 did. $^{13}$ Therefore the same practice may be suggested here, even if the state of preservation does not allow for certainty. The scribe perhaps wanted to make sure it is the right doxology that is being recited. Thus it is reasonable to suppose that the entire ostracon contained one very long prayer and 1.21 is containing the final phrases of the doxology, the beginning of which is in 11. 42-43 and which the scribe could not finish there due to a lack of space.

The prayer starts with thanksgiving for the salvation and safety of the congregation, then continues with a thanksgiving for creation, and ends with requests for safeguarding and assistance for a good life. These topics coincide with those of the so-called 'prayer of thanksgiving' or 'first prayer of the morning' of the present-day rite, ${ }^{14}$ although the wording is

\footnotetext{
${ }^{13}$ Ágnes T. Mihálykó, "Witnesses of a »Prayer of Offering « in Sahidic from the White Monastery and the Thebaid," JCS 17 (2015), 133.

${ }^{14}$ The text of this prayer is preserved to us in Greek in the Kacmarcik Codex (ed. William F. Macomber, "The Greek Text of the Coptic Mass and of the Anaphoras of Basil and Gregory According to the Kacmarcik Codex," Orientalia Christiana Periodica 43 [1977], 315-316), in Sahidic Coptic in an 11-12 ${ }^{\text {th }}$ century manuscript written in a Sahidic
} 
not shared. The first prayer of the morning is recited at the beginning of most Coptic services, including the morning offering of incense and the Eucharist. The prayer of this ostracon on the other hand seems to have had a more restricted use. The references to the day, the sun, and the light in 11. 17-19 position the prayer in a morning setting, which recommends the Eucharist or the morning prayer. In the churches of Western Thebes a daily morning prayer was recited and the Eucharist was said twice a week, on Saturday in the evening and Sunday in the morning. ${ }^{15}$ The potential reference to "this $\sigma 0 ́ v \alpha \xi ı$ " in 1.6 might indicate a setting in the Sunday morning Eucharist, as the corresponding verb бvvóyєiv acquired the specialized meaning "perform the Eucharist, take communion" in the Thebaid. However, in Shenoute's Canons oúva $\xi 1 \varsigma$ could still denote any religious assembly ${ }^{16}$ and it could have had this broader meaning when the text was composed for a certain service. The appearance of this word therefore did not necessarily restrict the use of this prayer to the Eucharist, it could also have been recited in the morning service of every day. ${ }^{17}$

\section{front}

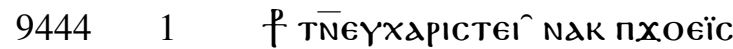

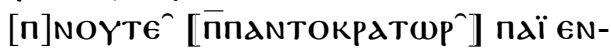

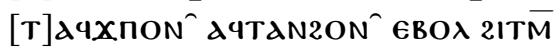

\footnotetext{
tainted with Fayumic forms, Prague, Or.Inst. MS I p.1-3 (ed. Valerie Hažmuková, "Miscellaneous Coptic Prayers," Archiv Orientální 8 [1936], 325-326, and in the Bohairic textus receptus (J.P. Bute, The Coptic Morning Service for the Lord's Day [London: J. Masters \& Co, 1882], 3-8).

${ }^{15}$ Mihálykó, The Christian Liturgical Papyri, 141 and 145.

${ }^{16}$ Bentley Layton, The Canons of Our Fathers: Monastic Rules of Shenoute (Oxford: Oxford University Press, 2014), 70.

${ }^{17}$ The prayer for the evening service in the same time and period can be identified in P.Rain. Unterricht Kopt. 197 verso (= BM EA 5895, ed. O.Brit. Mus. Copt. I p. 138, pl. 100,7) This coincides with the prayer of evening offering of incense in the present-day rite, which is recited only on days before a Eucharistic service. However, there is nothing to suggest that the prayer could not have had a broader use in the seventh century Western Thebes as the evening prayer for every day, regardless of the presence of a Eucharistic celebration. Indeed, Hans Quecke argued that in the late antique and medieval times the equivalent of the morning and evening offering of incense was still celebrated every day (Untersuchungen zum koptischen Stundengebet [Louvain-la-Neuve: Institute Orientaliste, 1970], 2-13). It is in such a daily morning and evening prayer, which later became associated with the Eucharist, that P.Berol. 9444+4790 and P.Rain. Unterricht Kopt. 197v could have its place.
} 


\begin{tabular}{|c|c|c|}
\hline & & $n \in$ \\
\hline & 5 & EPOK $^{\wedge}$ aY \\
\hline & & 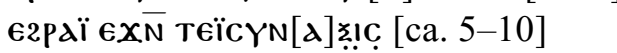 \\
\hline & & 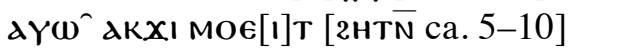 \\
\hline & & ETPENXח̣€ ג. . . [ca. 15?] \\
\hline 4970 & & ....]... ca. 12] \\
\hline & 10 & пENTAKTAMIO M[חТTHP $2 \bar{N}$ OYMNTTPM-] \\
\hline & & 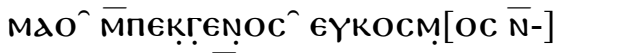 \\
\hline & & NEK2BHYE MN NEKMETNAN [OYY] \\
\hline & & EYCd`NNNEKKTICMA ETOYAdB. \\
\hline & & $M \bar{N}$ OYTdżC $\bar{N} N \in K T A M I O$ ETNA- \\
\hline & 15 & 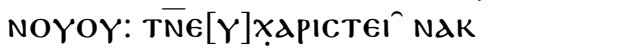 \\
\hline & & $\operatorname{na\lambda IN} T \bar{N}[\epsilon] Y X \lambda P I C T E I$ \\
\hline & & 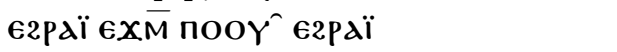 \\
\hline & & 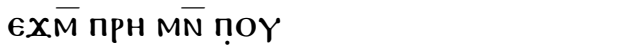 \\
\hline & & OGIN vac. \\
\hline
\end{tabular}

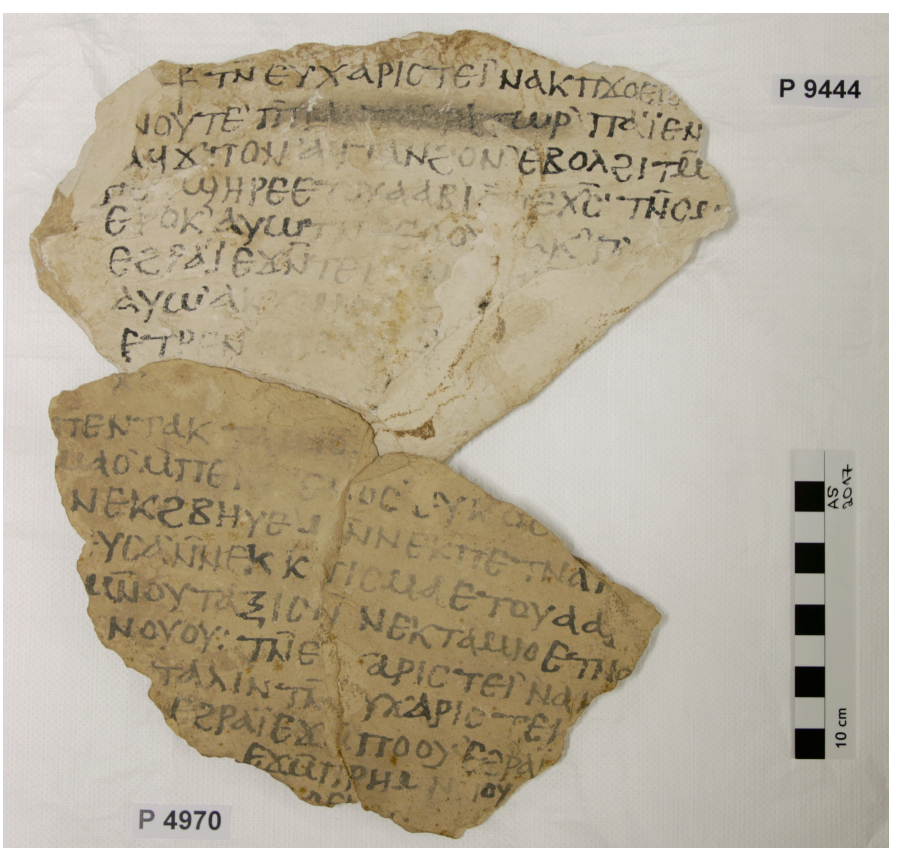

P.Berol. 9444+4970, S. 1

(C) Staatliche Museen zu Berlin, Ägyptisches Museum und Papyrussammlung 
back

944420.

[ca. 8-13? e] Ne2 2a [MHN]

[ca. 7-11] NeKTd[MıO? ca. 5-10

[ca. 6-10 $($ )] пेне: $x \in[$ ca. 6-11]

[ca. 5-8]. Yฯ NAN $\bar{M}$ [ca. 4-7]

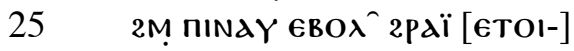

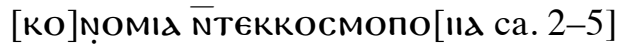

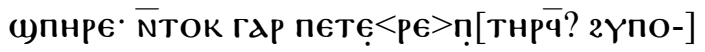

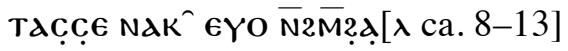

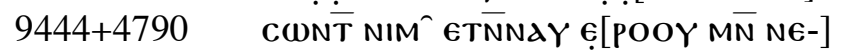

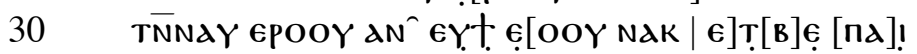

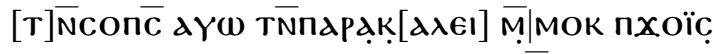

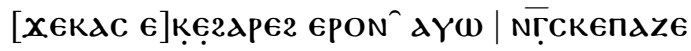

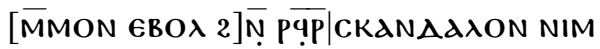

4790

$[M \bar{N} / 21 \mathrm{Ca} .2-3] 2 \in \mathrm{NIM}^{-} \mathrm{MN} N \mathrm{NAY} \cdot[\mathrm{d}-]$

35 [RI]त NIM 21 MOK2 $2 \overline{\mathrm{C}}$ N!M

aYW $N \bar{\Gamma} \operatorname{COYT\omega N} \bar{N} N$ [2HT]

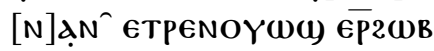

Ną THPOY חNOYTE ETt.

[n] THPQ NCT OYPOT NAN ET-

40

$[\overline{P N} \overline{\bar{P}}]$ nETNANOYG MN $[$ RETP]

[a] NaK $\bar{N}$ NEN2OO[Y TH-]

poY $x \in T \omega K$

TE TбOM

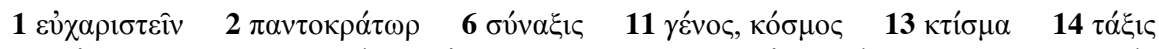

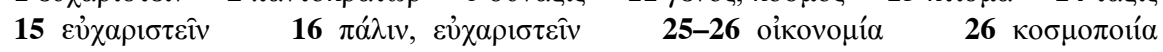

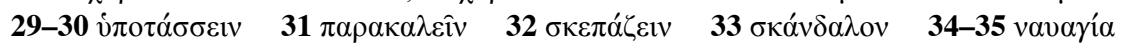

$\mathbf{1 2}$ Acts 17:29 $\mathbf{1 3}$ Wis. 13:5 27-28 1 Cor. 15:28 $\quad$ 29-30 Col. 1:16 $\mathbf{3 6} 2$ Thess. 3:5

\section{Translation}

We give thanks to you, Lord I God \{Almighty , he who I acquired us, who quickened us through I his holy Son Jesus Christ, we bless $\left.\right|^{5}$ you and we glorify you, Lord, I for this service ... I and you showed us the way... I so that we acquire... $\left.\right|^{10}$ who created everything in a richness $I$ for your offspring to the adornment of I your things and your good things, I to a 
beauty of your holy creatures I and an order of your good creatures: $I^{15}$ we give thanks to you, I again we give thanks I for the day, for I the sun and the I light I ... \{ever amen $\}$ I . . your creatures (?) I ... wonder (?): that I ... to us $\left.\right|^{25} \ldots$ in glimpsing (?) the I economy of your creation of the world (in a?) I wonder, because you are to whom (everything?) I is subject, being servant... I all creatures visible and $\mathrm{I}^{30}$ invisible, glorifying you, because of this I we pray and beseech you, Lord, I that you preserve us and protect I us from all those who cause us to stumble $\mid$ and all... and all shipwreck $\left.\right|^{35}$ and all grief I and direct the hearts I for us so that we wish to work I for you (?) all, God who gives I all, give us zeal $\left.\right|^{40}$ to do what is good and what I pleases you in all our days I because yours I is the power ${ }^{(21)}<$ (and the glory forever and) ever amen>.

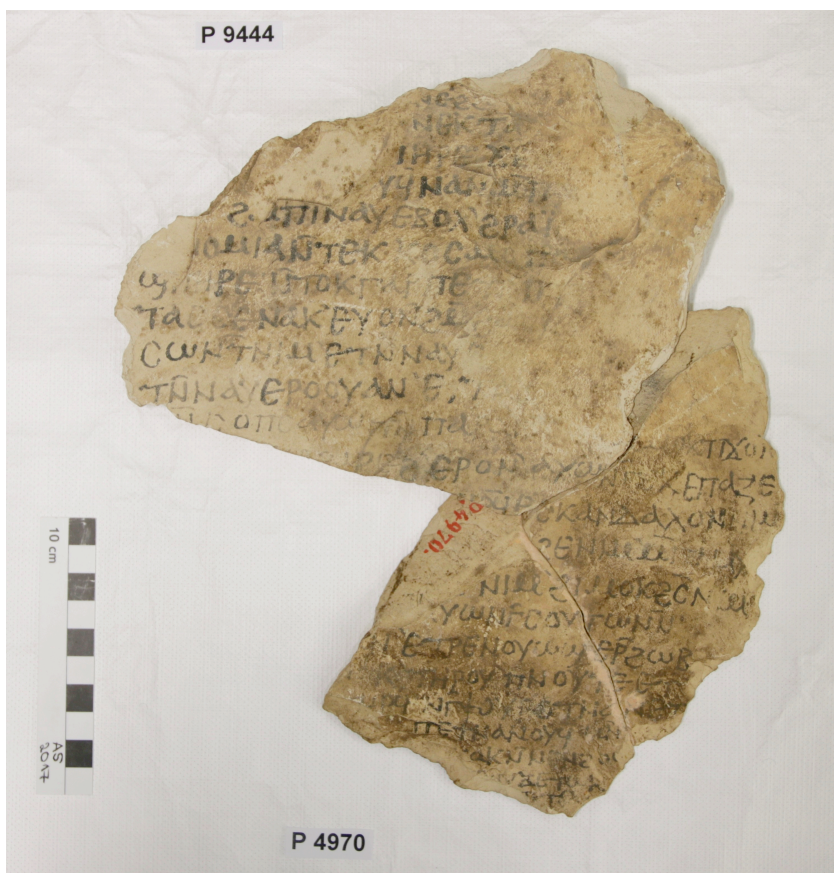

P.Berol. 9444+4970, S. 2

(C) Staatliche Museen zu Berlin, Ägyptisches Museum und Papyrussammlung 


\section{Commentary}

1 TÑeYXapictei nak: The same phrase opens the call for prayer at the beginning of the first prayer of the day and follows the address of God at the beginning of the prayer itself (Bute, The Coptic Morning Service, 3-4). In the Sahidic translation of Prague, Or. Inst. MS I p. 11.1 and p. 2 1. 1 the Coptic equivalent ()enzєmat is used.

2 [n]NOYT $\bar{\epsilon}$ [ח by habitude to write the customary Coptic liturgical address for God, "Lord God Almighty", but realized that his exemplar did not have the epithet and deleted it. This level of attention to an exemplar is remarkable for a liturgical prayer, where such extent of variation often goes unnoticed, see e.g. Mihálykó, "Witnesses of a »Prayer of Offering «", 131-135.

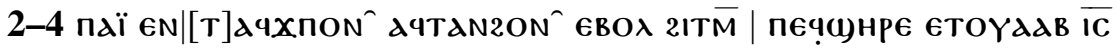
$n \in \overline{\mathbf{X C}}$ : The epithet of God introduces a typical topic of thanksgiving. The sequence "acquire us" and "quicken us" is reminiscent of the sequence

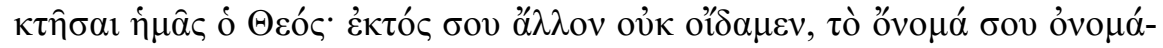

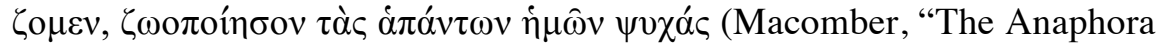
of Saint Mark", 80) of the intercession for the peace of the anaphora of St. Mark/Cyril, the first part of which relies on Isa. 26:13. Our prayer might have drawn inspiration from this sequence.

6 Teïc $Y N[\alpha]$ :!lc: In the first prayer of the morning thanksgiving is offered for being brought "to this hour" (Prague, Or. Inst. MS I p. 2.5-6:

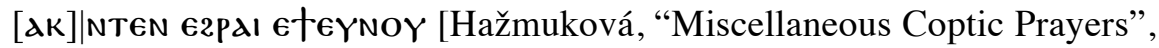
327]), and then God is asked to safeguard the congregation for "this holy day" of the service. The missing text at the end might be something along the line "you gave us", e.g. NTak† Nan?

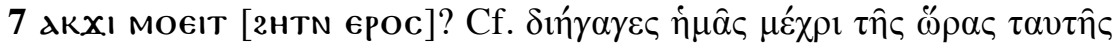
in the Greek of the first prayer of the morning (Macomber, "The Greek Text of the Coptic Mass", 315), but the verb is translated to Coptic as גKNTEN E2Pal in Prague, Or. Inst. MS I p. 2.5-6.

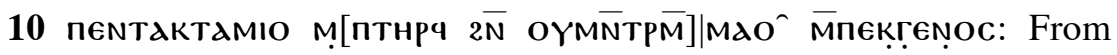
thanksgiving for salvation and preservation the prayer goes over to a thanksgiving for creation. $[2 \bar{N}$ OYMN TPM $] \mid M \lambda O$ can also be reconstructed as $2 \bar{N}$ TEKMNNTPMMdO, but the parallel of Titus 3:6 חגı ENTג EXWN 2N OYMNTPMmdo "(the Holy Spirit) whom he poured out on us generously through Jesus Christ our Saviour" (Horner, The Coptic Version 
Vol. $V, 546)$ supports the reconstruction with oy. The expression nєкгеNOC for humankind finds a parallel in Acts 17:29 EANON חгENOC $6 \mathbf{E}$ mпnoYte "being the offspring of God" (G.W. Horner, The Coptic Version of the New Testament in the Southern Dialect. Vol. VI. The Acts of the Apostles [Oxford: Clarendon Press, 1922], 414).

11-15 The parallel constructions do not lack a certain rhetorical quality. Remarkable is the word кó $\sigma \mu$ os in the classical meaning 'adornment, beauty', which is rare in patristic authors (A Patristic Greek Lexicon [ed. G.W.H. Lampe; Oxford: Clarendon Press, 1962], 771a), although it appears a few times in the Septuagint (Sir. 6:30, 21:21 or Isa. 3:19), where the Sahidic translation keeps the word (see Paul Laguarde, Aegyptiaca [Göttingen: Dietrich, 1883], 116 and 142; Agostino Ciasca, Sacrorum Bibliorum Fragmenta Copto-Sahidica, Vol. II [Romae: Typis S. Congregationis, 1889], 221). The expression "beauty of your creatures" finds a

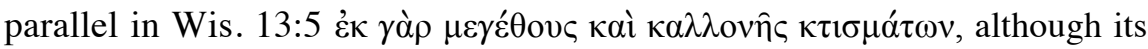

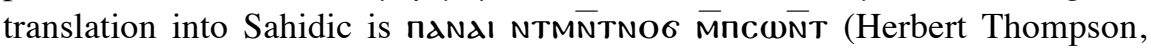
The Coptic (Sahidic) version of certain Books of the Old Testament: from a papyrus in the British Museum [London: Oxford University Press, 1908],

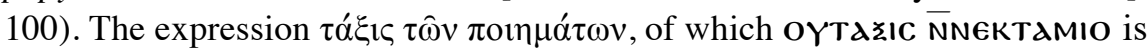
likely to be a translation, is an expression used exclusively by Cyril of Alexandria (glaph. pent. [PG LXIX 429 1. 31-32] and hom. pasch. 12, 2.66 [SC 434, p. 46]). The parallel of the construction in the second two clauses may indicate that NEKnETNAN [OYq] served in the original also as an adjective ("the order of your good things") and was mistranslated in the Coptic version.

15-16 The repetition of TNEYXapıcteI NaK either indicates that something was dropped, or it was meant as highly rhetorical.

17-19 The objects of thanksgiving, the day, the sun, and the light imply the morning as the time of the prayer. Where the two fragments join in 1. 18 , fragment B seems to have been mutilated already when the ostracon was written, and a bit of space was jumped over right under the $\mathbf{H}$ of the previous line. After $\mathrm{N}^{-}$in 1.19 a space equalling two or three letters was left empty, as the scribe reached the bottom of the front and did not wish to split the new word.

20 There seems to be traces of ink on the broken upper edge of the back. This might belong either to a letter or potentially a cross or a staurogram. 
$21[\epsilon] \mathrm{NG} 2 \mathrm{a}[\mathrm{MHN}]$ : If this was the end of a prayer, then the first prayer would have close to no space for a request, expect for the lost 1. 20. Therefore, it is likely that 1.21 is out of place here, see introduction. The doxology probably followed the pattern of the doxology of the Lord's prayer in Matt. 6:13 (G.W. Horner, The Coptic Version of the New Testament in the Southern Dialect. Vol. I. The Gospels of S. Matthew and S. Mark [Oxford: Clarendon Press, 1911], 46) and had the form тшк те T6OM [MN nEOOY ()ג ENE2 $\bar{N} \in$ ] water, it occupied only 1.21 and the sign in 1.20 was probably a cross.

25-27 Due to the loss of the text the meaning remains uncertain. NaY ЄвО $\lambda$ might mean 'to see' as opposed to 'being blind', but this does not fit well with 2paï. Since there is little missing at the end of 1.25 , the next expression might be a direct object of nINAY ЄBOג. The expression oiko-

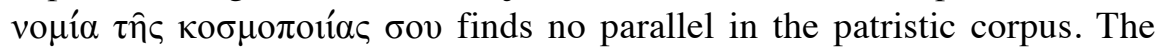
translator decided to leave the Greek words in place either because he expected his audience to know or figure out the meaning of the words, or because he was struggling to find a good equivalent in Coptic. The connection to the word thing along the way 'in a wonder, wondering', e.g. $[\mathbf{\epsilon N \overline { P }}] \mid$ ()пнре? $[2 \bar{N}$ оү]|()пнре?

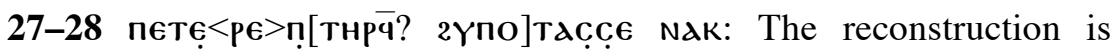
based on the parallel of 1 Cor. 15:28 2OTAN $\Delta \in$ EP()גN NKa NIM 2YחO-

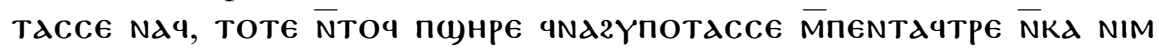
2Ynotacce Naq "when all things have been made subject to him, then the Son himself will be made subject to him who made everything subject to him" (G.W. Horner, The Coptic Version of the New Testament in the Southern Dialect. Vol. IV. The Epistles of Saint Paul [Oxford: Clarendon Press, 1920], 306). However, the $\boldsymbol{n}$ before the abraded text is rather certain and cannot be a p. Thus some missed letters and a synonym of NKa NIM has to be supposed.

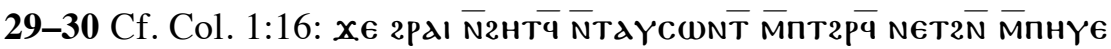

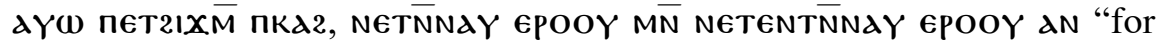
in him all things were created: things in heaven and on earth, visible and invisible" (Horner, The Coptic Version Vol. V, 324), which is quoted also in the Nicene and the Niceno-Constantinopolitan Creed. The verb of the scriptural quotation is turned into a noun. The connection to the previous clause remains unresolved. 
30-35 The request for protection from various evils is also the central element of the first prayer of the morning, but the vocabulary is only marginally overlapping. In the first prayer of the morning the verbs 2ape 2 and cкenaze figure in the thanksgiving part. скепдze is the first verb in both the Bohairic (Bute, The Coptic Morning Service, 3-4) and the Sahidic (Prague, Or. Inst. MS I p. 1.6 and p. 2.3, Hažmuková, "Miscellaneous Coptic Prayers", 325-326) translations, whereas ape2 is used only in the Bohairic to translate the Greek $\varphi v \lambda \alpha ́ \sigma \sigma \omega$, the Sahidic applies poeıc (Prague, Or. Inst. MS I p. 1.7 and p. 2.4). The first prayer of the morning also lists evils that are requested to be taken away from the congregation rather than averted, but they have no overlap with this list.

33 Ṇpạp $\mid$ CKANAdגON NIM: The request to protect from those who cause one to stumble may be related to Jesus' strict admonitions against such things and people, including his saying to gouge out the eye and cut off the hand which causes one to stumble (Matt. 5:29-30, 18:8-9, Mk. 9:43, 47), and his warning against those who cause the faithful to stumble (Matt. 18:6-7, Mk. 9:42, Lk. 17:2).

34 ]26: Due to the lack of parallels the word cannot be reconstructed with certainty, but possibilities can be advanced. The most obvious is $2 \epsilon$ 'destruction, fall'. The probable amount of letters lost at the left margin speaks against this solution, but since ostraca have uneven edges, it cannot

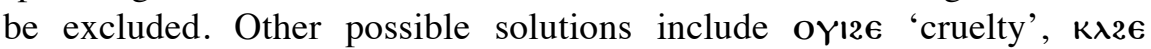
'blow', or on the more earthly level oyoze 'scorpion'.

34-35 NaY $[\alpha \mid r i] d:$ The letters at the end of 1.34 and the $\alpha$ in 1.35 are rather certain, which suggests the Greek word vavayía "shipwreck". $v \alpha v a \gamma i \alpha$ is a rare classical expressions, but it fits in the series of misfortunes and plagues that the congregation should be freed from and it figures in various church fathers, including Cyril of Alexandria (dogm. [ed. Pusey, Vol. III] p. 563 1. 13), where it can have a spiritual meaning as

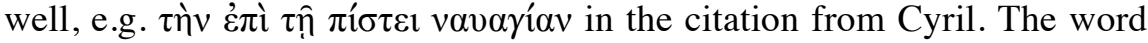
probably has a spiritual rather than concrete meaning here as well. As the word is rather infrequent, the translator may have left it in Greek because he ignored the meaning.

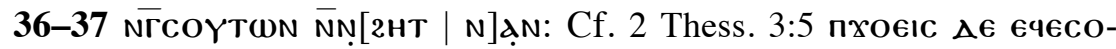

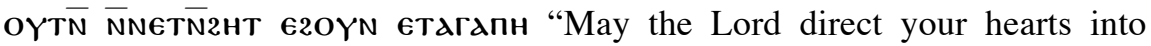
God's love and Christ's perseverance" (Horner, The Coptic Version Vol. V, 
426). Instead of resorting to the possessive article, the translator chose the dative, perhaps inspired by a dative $\dot{\eta} \mu i ̂ v$ in the Greek original.

37-38 етPENOY between $\overline{\mathrm{P}} 2 \omega \mathrm{B}$ and тнроY is irregular, but it can be read with some certainty.

39-41 Requests for help to do God's will are not particularly frequent in liturgical prayers. Besides O.CrumST 17, a blessing from Western Thebes which asks God to "give us the means that we do his will" (11. 1011), a private prayer from the Monastery of Epiphanius, P.Mon. Epiph. 44

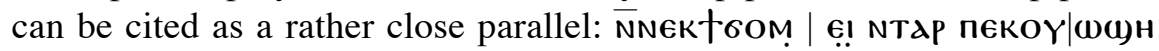
NNE2O|OY THPOY $\mid[\ldots]$ "give me power to do your will, all the days (of my life)" (11. 10-15). 